Department of Anatomy (Prof. U. FukuYama) and Brain Research Institute (Prof. Y. HaGihara), Chiba University School of Medicine, Chiba, Japan

\title{
Formation of Neuromuscular Junctions in Embryonic Cultures*
}

\author{
Yutaka SHImADA and Masaakira Kano
}

Received March 31, 1971

Summary. Formation of neuromuscular junctions in embryonic cultures has been reviewed. Anatomical and electrophysiological evidence has been presented which demonstrates the formation de novo of synaptic contacts between nerve and muscle in culture; in (1) organ cultures of spinal cord explanted intact with attached myotomes, $(2)$ organ cultures of in vitro coupled explants of spinal cord and skeletal muscle fragments, and (3) monolayer cultures of dissociated myoblasts confronted either with spinal cord fragments or cells. Innervation across species lines has also been demonstrated in explants of spinal cord and skeletal muscle from different species These cultures should provide a useful system for analysis of the mechanisms underlying the trophic and other interactions during neuromuscular development.

\section{Contents}

I. Introduction.................

II. Organ cultures of spinal cord explanted with attached myotomes .................. 97

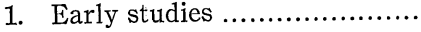

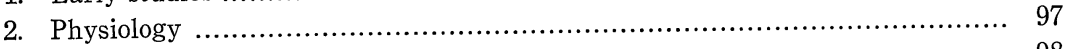

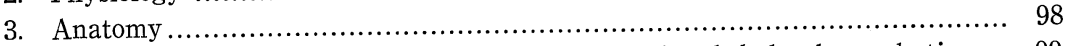

III. Organ cultures of in vitro coupled explants of spinal cord and skeletal muscle tissues 99

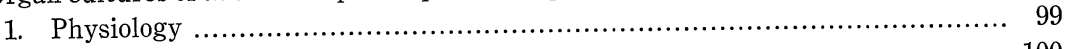

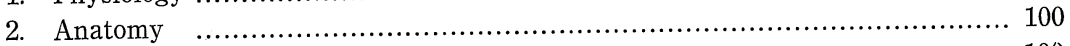

3. Innervation in cultures of unusual tissue combinations ..................... 100

IV. Monolayer cultures of dissociated myoblasts confronted either with spinal cord frag-

1. Anatomy of neuromuscular junctions in monolayer cultures of myoblasts confronted with spinal cord fragments ........................................ 101

2. Anatomy of neuromuscular junctions in monolayer cultures of mixed spinal cord and skeletal muscle cells .............................................. 101

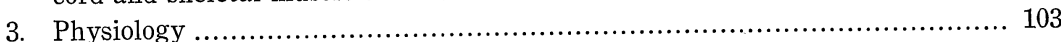

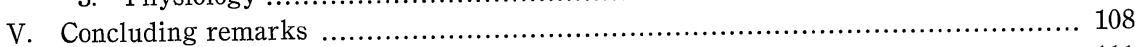

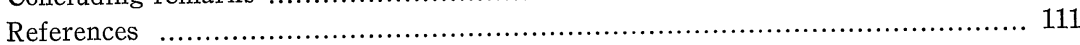

*Supported in part by a grant to Y. Shimada from the Muscular Dystrophy Associations of America, Inc. 


\section{Introduction}

It was not until 1907 that a reliable and definite technique for culturing cells outside of the body was reported by HARRISON. Since the earliest applications of these methods, both nerve and muscle tissues have been the object of investigations (see review by Murray, 1965a, 1965b). Particularly, the demonstration of nerve-muscle junction formation in vitro attracted the attention of some of the foremost tissue culturists active in the first half of this century, but it was not until recently that decisive results began to appear.

In the pioneer work in tissue culture, HARRISON (1907), observing cultured frog embryo tissue, noted certain patterns of spontaneous muscle contractions which were correlated with the presence of spinal components in the explant. In extention of HARRIson's work, SzEPSEnwol $(1946,1947)$ explanted cord-somite regions of chick embryo, and provided the possibility of the development of neuromuscular relationships in culture. He reached this conclusion after observing the patterns of contraction of innervated and non-innervated muscle and the response to pharmacological agents.

However, in view of the common occurrence of various types of spontaneous muscle contractions in completely isolated muscle explants (CRAIN, 1965; MURRAY, 1965a), interpretations regarding innervation based solely on visual observations may not be reliable (CRAIN, 1970). Thus, direct electrophysiologic evidence is required to establish whether neuromuscular transmission can develop in cultures of cord-somite regions; this was proven by several investigators (CRAIN, 1964, 1970; Corner and Crain, 1965; Peterson, Crain and Murray, 1965). Morphologic evidence of the formation of neuromuscular junctions in such cultures provided further support to the view that organized cellular interrelationships in vivo can continue to develop and be maintained under isolated conditions in culture (BORNSTEIN and Breitbart, 1964; Bornstein, Iwanami, Lehrer and Breitbart, 1968; Veneroni, 1968a, 1968b; Veneroni and Murray, 1969).

In the past few years it has been investigated whether neuromuscular junctions can develop not only in cultures where neuromuscular tissues were explanted without disruption of the early topographic relationships already established in the embryo, but also in cultures of spinal cord and skeletal muscle tissues paired in vitro. The following culture systems have been employed: spatially separated explants of spinal cord and skeletal muscle (CRAIN, 1968, 1970; CRAIN, AlfEI and Peterson, 1970; Peterson and Crain, 1968, 1970; Peterson, Alfei and Crain, 1969, 1970; JAmEs and Tresman, 1968; NAKAI, 1969), cultures of completely dissociated muscle fibers confronted with spinal cord fragments (VENERONI, 1968a, 1968b; JAMES and Tresman, 1969; 'Veneroni and Murray, 1969; Kano and Shimada, 1971a, 1971b) and cultures of dissociated and mixed skeletal muscle and spinal cord cells (SHIMADA, 1968; Shimada, Fischman and Moscona, 1969a, 1969b; Fischbach, 1970). All of these studies showed morphological and/or physiological evidence of de novo formation of neuromuscular synapses. Peterson, Alfei and Crain (1969, 1970), Peterson and CRAIN (1970) and CRAIN, Alfei and Peterson (1970) showed, furthermore, that organized motor endplates can develop even when the cord and muscle tissues are explanted from fetuses of different species. 
In this monograph we will review the morphological and electrophysiological studies of the de novo formation of neuromuscular junctions, and we hope that this paper might serve as a springboard for further progress in examining the mechanisms of innervation and particularly the problems of specificity in nerve-muscle association and other aspects of cell contacts and "recognition" during neuromuscular development.

\section{Organ Cultures of Spinal Cord Explanted with Attached Myotomes}

\section{Early studies}

HARRISON (1907) removed small fragments of neural tube from an early frog embryo (shortly after the closure of the medullary folds) and suspended them in hanging drops in clotted lymph from the adult animal in an attempt to prove the contention of HIs and CAJAL that nerve fiber is formed as the outgrowth of a single cell. In this original observation on the living developing nerve fiber he included a short description concerning the differentiation of muscle and the added feature of contractility when the myotome was left attached to a piece of the medullary cord.

The possibility that neuromuscular junctions might develop in culture was advanced by SzePsenwol's studies $(1946,1947)$ of chick embryo somite-spinal cord tissues. Using the hanging drop technique, he cultivated chick embryo myotomes together with and without the corresponding fragment of the spinal cord, and found the difference between the activity of these two muscles. The former muscle contracted arhythmically while the latter, rhythmically. Stimulations with condenser discharge shocks showed higher excitability in the former ones than in the latter. After curarization, the former explants lost spontaneous activity and their threshold of excitability increased 10 times or more. From these results he considered that the contractions in the former case were neurogenic due to the activity of the nerve cells present in culture.

\section{Physiology}

The early studies of HARRISON (1907) and SzEPSENwol $(1946,1947)$ on cultured cord with attached myotomes have been extended with electrophysiological experiments on explants of embryonic neuromuscular tissue of the mouse (CRAIN, 1964, 1970), rat (Peterson, Crain and Murray, 1965) and frog (Corner and Crain, 1965) (see review by MURRAY, 1965a, 1965b; CRAIN, 1966).

CRAIN $(1964,1970)$ explanted cross sections of the dorsal half of 12-13 day mouse embryos on collagen-coated coverslips. The spinal cord and skeletal muscle components continued to differentiate, and at 1-2 months in vitro characteristic neuromuscular transmission was demonstrated electrophysiologically. Following a critically localized stimulus to the cord or ventral root, skeletal muscle responses began with latencies of at least several msec after the onset of spike barrages in the spinal cord. Synchronized contraction of large groups of muscle fibers was often seen concomitant with the cord-evoked muscle potentials. D-tubocurarine selectively (and reversibly) blocked these cord-evoked muscle responses within a few minutes at levels which still permitted direct activation of the muscle fibers. At the lower dose levels single shocks applied to the cord could not elicit muscle contractions, 
but repetitive stimuli were still effective. Similar phenomena were also demonstrated in cultures of rat embryo cord with attached myotomes (PETERSON, CRain and MurRay, 1965). Strychnine increased the duration and amplitude of cord afterdischarges, and vigorous, repetitive muscle contractions occurred in association with this augmented neural activity. Eserine led to repetitive muscle twitching following a single cord stimulus, whereas the bioelectric activity of the cord tissue was unaffected at this dosage. Based on these experiments, CRAIN concluded that longterm cultures of fetal spinal cord explanted together with attached myotomes may develop and maintain a remarkable degree of functional organization resembling their in situ counterparts.

CORNER and CRAIN (1965) carried out a far more extreme test of the capacity of isolated neuromuscular tissue to self-differentiate in vitro with explants of frog neurulae. The prospective spinal cord was excised together with underlying presumptive axial muscle and cultured in a relatively simple, balanced salt solution. Spontaneous muscle twitches began to occur during the first week in vitro. Electrophysiological data indicated that the characteristic, spontaneous bursts of muscle contractions could be triggered by periodic bursts of neural activity. These results were consistent with analyses of cultured mouse and rat cord-myotomes (CRAIN, 1964, 1970; Peterson, Crain and Murray, 1965).

\section{Anatomy}

Anatomical evidence of the development of neuromuscular junctions in the cultures of cord-somite regions was furnished later. In long-term cultures of en bloc preparations of cord-somite regions from 10-16 day mouse embryos (BoRNSTEIN and Breitbart, 1964; Bornstein, Iwanami, Lehrer and Breitbart, 1968), myelinated axons could be seen in the living state to penetrate into the masses of muscle tissue where they lost their myelin and appeared to terminate, suggesting the presence of neuromuscular junctions. Silver impregnations revealed terminal expansions and endings en passage on muscle fibers after 7 days in vitro. Cholinesterase $(\mathrm{ChE})$ activity (KOELLE and FRIEDENWALD, 1949) at the nerve endings could be demonstrated after the 5th-6th day in vitro. Although many endings maintained a simple, plate-like, primitive configuration, some possessed infoldings of the subneural apparatus after maturation in culture. The $\mathrm{ChE}$ reactions were blocked by the exposure of cultures to diisopropylfluorophosphate. Electron microscopic examination revealed that the junction consisted of a shallow trough occupied by an axonal ending filled with synaptic vesicles and covered with a teloglial cell. The synaptic space was about $500 \AA$ in width and synaptic folds of the post-synaptic sarcolemma could not be found. The ChE preparations (KARNOvSKY, 1964) revealed reaction products mainly in the primary synaptic cleft, and small amounts in the space between the teloglial cell and the axon terminal as well as on the sarcolemma in the immediate vicinity of the endplate. Veneroni (1968a, 1968b) and Veneroni and Murray (1969) also presented morphological evidence that characteristic neuromuscular junctions had been formed in explants of the 10 day mouse and 72-80 hour chick embryos by silver impregnation. These results reinforced the electrophysiological observations (Section II 2).

It is unlikely that neuromuscular synapses had been established prior to removal 
of the tissue from the 10-16 day mouse, $72-80$ hour chick or neurula frog embryos. Evidence from published physiological and morphological studies (Gonzalez, 1932; Windle, 1931, 1934; Windle, Minear, Austin and Orr, 1935; Wingle and Baxter, 1936; Kupfer and Koelle, 1951; Zelena and Szentágothai, 1957; Csillik, 1960; Diamond and Miledi, 1962; Anggard and Ottoson, 1963; Corner, 1964a, 1964b; Filogamo and Gabella, 1967; Hirano, 1967a, 1967b; Teräväinen, 1968; Kelly and

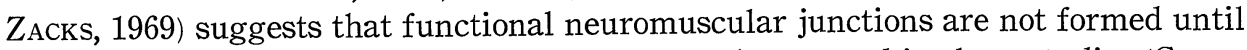
stages of development well beyond that of the embryos used in these studies (CRAIN, 1964, 1970; Bornstein, IwANAmI, Lehrer and Breitbart, 1968). Thus, it was concluded in these studies that neuromuscular junctions developed and differentiated during the tissue's in vitro existence.

\section{Organ Cultures of in vitro Coupled Explants of Spinal Cord and Skeletal Muscle Tissues}

In the cultures of cross-sections of embryos (Section II), the neural and muscle tissues were explanted together prior to synaptogenesis but without disruption of the early topographic relationships already established in the embryo. Thus, neuromusclar junctions formed in such cultures represent simply the further development in vitro of the anlage previously formed in vivo. As a step towards studying innervation mechanisms, it is natural to wonder whether neuromuscular junctions can be formed de novo in cultures of completely separated explants of nerve and muscle tissues. These experiments have been done by several investigators (CRAIN, 1968, 1970; James and Tresman, 1968; Peterson and Crain, 1968, 1970; Nakai, 1969; Peterson, Alfei and Crain, 1969, 1970; Crain, Alfei and Peterson, 1970). The results of these studies showed electrophysiological and anatomical evidence of de novo formation of neuromuscular synapses.

\section{Physiology}

Pairs of fetal spinal cord and skeletal muscle fragments $\left(1 \mathrm{~mm}^{3}\right)$, isolated from 14-15 day rodent fetuses (mice and rats), were explanted $0.5-1 \mathrm{~mm}$ apart-one fragment generally presented to the other after days or weeks in vitro (CRAIN, 1968, 1970; PEtERSON and CRAIN, 1970). Bioelectric studies were made after a substantial number of myelinated neurites had been observed to grow across and penetrate into the muscle explants (after cord-muscle coupling periods of 14-60 days in vitro), and similar results as in the cultures of cord-myotome explants (Section II 2) were obtained. Selective stimulation of cord or ventral-root loci evoked widespread, synchronized twitches in the muscle explant. Simultaneous extracellular recordings of the cord and muscle responses to local cord stimulation showed that muscle responses began with latencies of several msec after onset of cord spike-barrages. Synchronized cord and muscle discharges also occurred spontaneously, at times, especially after introduction of strychnine. D-tubocurarine selectively and rapidly blocked neurally evoked contractions, while electric stimuli applied directly to muscle fibers were still effective. Many apparently non-innervated fibers, on the other hand, showed spontaneous fibrillations which were not altered by cord stimuli nor blocked by d-tubocurarine treatment. 


\section{Anatomy}

Morpholoical studies of the formation of neuromuscular junctions in de novo coupled neuromuscular tissues have been reported by JAMEs and TrEsman (1968), Peterson and Crain (1968, 1970), and Nakai (1969). Peterson and Crain (1968, 1970) fixed the cultures described under Section III 1, and stained them with silver and ChE (with the method of Koelle and Friedenwald, 1949). Myelinated ventral-root fibers were seen to bridge the gap between the cord and muscle explants and to arborize and terminate on cross-striated muscle fibers. ChE-positive loci appeared by 3 weeks. In cultures maintained for 5-11 weeks, the more differentiated motor endplate structures showed characteristic subneural infoldings, increased soleplate sarcoplasm, and terminal Schwann cells. In these cultures spinal cord fragments were explanted with attached meningeal tissues. The presence of meninges might have accounted for the formation of complex endplate structures with greater similarities to those in vivo.

NAKAI (1969) has observed the formation of neuromuscular junctions when fragments of spinal cord and muscle from 4-14 day chick embryos were cultured for several weeks (by the roller-tube method). The nerve fibers in these cultures were not ensheathed by Schwann cells, and the structure of the ChE (KARNovsky and Roots, 1964) localizations at the junctions appeared to be relatively simple.

JAMES and TRESman (1968) have observed by electron microscopy the early 2-4 day neuritic contacts with muscle in cultures of chick embryo skeletal muscle coupled with spinal cord. Electron micrographs of nerve terminals on muscle showed structures of simple synapses, including vesicles, an appropriate gap separating adjoining membranes containing electron-dense material, and thickening of the postsynaptic membrane. A Schwannian component was lacking in these neuromuscular junctions, and a basement membrane was not apparent on the muscle plasma membrane. Based on these observations they suggested neuromuscular junction formation within a brief period of culture.

\section{Innervation in cultures of unusual tissue combinations}

Establishement of neuromuscular relationships have also been reported in unsual tissue combinations: between fetal spinal cord and adult skeletal muscle, and between cord and muscle from different genetic origins. The following in vitro tissue couplings were done: (1) fetal rodent spinal cord and adult rodent skeletal muscle (Peterson, Alfei and Crain, 1969; Crain, Alfei and Peterson, 1970), (2) fetal rodent cord and adult human muscle (Peterson, Alfei and Crain, 1969; Crain, Alfei and Peterson, 1970), and ( 3 ) fetal rat cord and fetal mouse muscle (Crain, 1970; Peterson, Alfei and Crain, 1970; Peterson and CRAin, 1970). The results were consistent with those in cultures of in vitro coupling of tissues from the same species (Section III 1 and 2). After coupling periods of 2-7 weeks in vitro, new motor endplates could be demonstrated with $\mathrm{ChE}$ reactions. Transmission of neuromuscular impulses could be demonstrated by electrophysiological examination of the coupled explants. Selective cord stimulation evoked widespread muscle contractions. Synchronized cord and muscle discharges also occurred spontaneously. D-tubocurarine selectively and rapidly blocked neurally evoked contractions. 


\section{Monolayer Cultures of Dissociated Myoblasts Confronted Either with Spinal Cord Fragments or Cells}

The culture systems described above have the intrinsic limitations of using the muscle either explanted in such a manner as to preserve the topographical relationships with the spinal cord undisturbed (Section II), or differentiated in vivo to retain its receptivity to innervation (Section III). In order to conduct a more rigorous examination of junction development de novo, muscle fibers differentiated in vitro from trypsin dissociated somatic muscle have been used. These cultures were confronted either with ventral spinal cord fragments (VENERONI, 1968a, 1968b; JAMES and Tresman, 1969; Veneroni and Murray, 1969; Kano and Shimada, 1971a, 1971b) or cells (Shimada, 1968; Shimada, Fischman and Moscona, 1969a, 1969b; Fischbach, 1970).

\section{Anatomy of neuromuscular junctions in monolayer cultures of myoblasts con- fronted with spinal cord fragments}

Veneroni (1968a, 1968b) and Veneroni and Murray (1969) have demonstrated neuromuscular junctions between spinal cord fragments and trypsin dissociated muscle by light microscopical and ChE techniques (KARNOvsKY and Roots, 1964). Segments of chick spinal cord of 7-11 days incubation were explanted with dissociated muscle tissue from the same embryo or an embryo of different age. A high degree of differentiation was achieved by both nervous and reaggregated muscle tissue. Exploring nerve fibers from the cord explants made contact with the sarcoblasts, and areas of ChE activity appeared in the sarcolemma of the newly integrated fibers. Simple neuromuscular junctions formed de novo.

Electron microscopy of junctions in this culture system has been done by JAMES and Tresman (1969). Trypsin dissociated somatic muscle from 11 day chick embryos was cultured upon a collagen substrate, and later confronted with 7-9 day chick lumbar spinal cord. The results showed neuromuscular junction formation during a 2-4 day period in which spinal cord and muscle were confronted. The cytologic features of the resulting junctions appeared to be relatively immature and were similar in appearance to those reported by JAMES and TRESMAN (1968) (Section III 2).

\section{Anatomy of neuromuscular junctions in monolayer cultures of mixed spinal cord and skeletal muscle cells}

Shimada (1968) and Shimada, Fischman and Moscona (1969a, 1969b) have determined that neuromuscular junctions can also develop at the level of single cell interactions in monolayer cultures of mixed spinal cord and skeletal muscle cells. Both the skeletal muscle and ventral spinal cord were dissociated prior to explantation; trypsinized leg muscle cells from 12 day chick embryos were grown on collagencoated coverslips, and similarly trypsinized spinal cord cells from 6 day embryos were inoculated into the 0-2 day muscle cultures. In the early stages of these cultures, bulbous swellings along the length of the neurofibers were observed at points of contact with myotubes or muscle fibers after silver impregnation ( 6 days in vitro: Fig. 1a, 1b; 14 days in vitro: Fig. 2-6). Nerve terminals at these junctions have been traced to their perikaryonal origin. On the basis of the size and abundance 


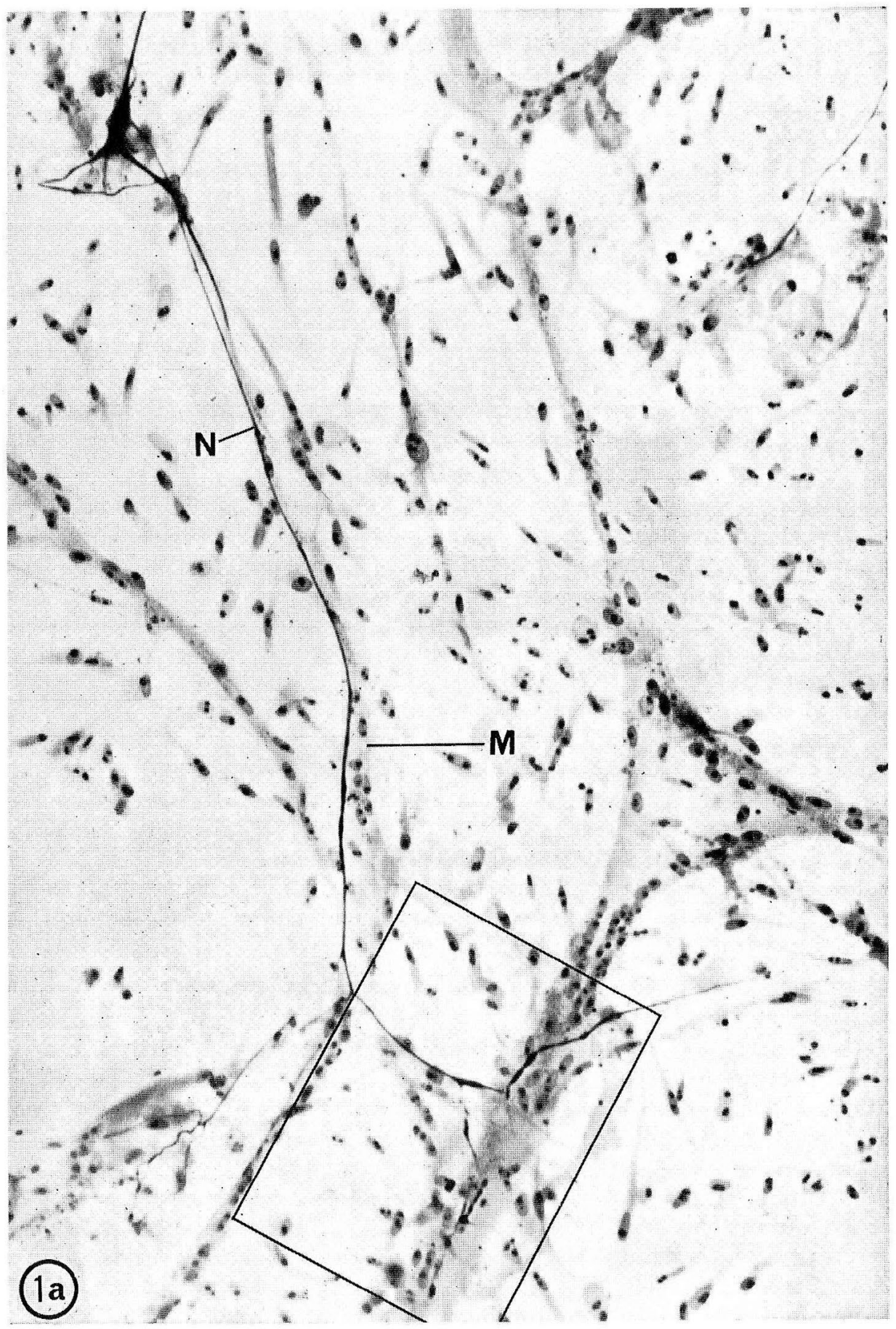

Fig. 1-7. Silver stained whole-mount preparations of monolayer cultures of mixed spinal cord and skelelal muscle cells. 
of neurofibrillar development, these cells might well be classified as motor neurons. By 20 days in culture axon terminals of greater complexity suggestive of en plaque endings were found (Fig. 7a, 7b) rather than the en grappe type nerve endings seen in the earlier stages. In these latter cultures small oval nuclei appeared to be associated with these nerve terminals, which were tentatively identified as Schwann cell nuclei. Electron micrographs of cultures after a 10-14 day period in vitro showed that the intercellular contacts possessed structural characteristics of a neuromuscular synapse, although still relatively simple and immature (Fig. 8). No data regarding $\mathrm{ChE}$ localization were reported in either of these studies of neural coupling with dissociated muscle cells (Section IV 1 and 2).

\section{Physiology}

Electrophysiological studies have been performed on the development in vitro of synaptic transmission between dissociated skeletal muscle cells and spinal cord cells (FischbAch, 1970) or spinal cord fragments (Kano and SHimada, 1971a, 1971b).

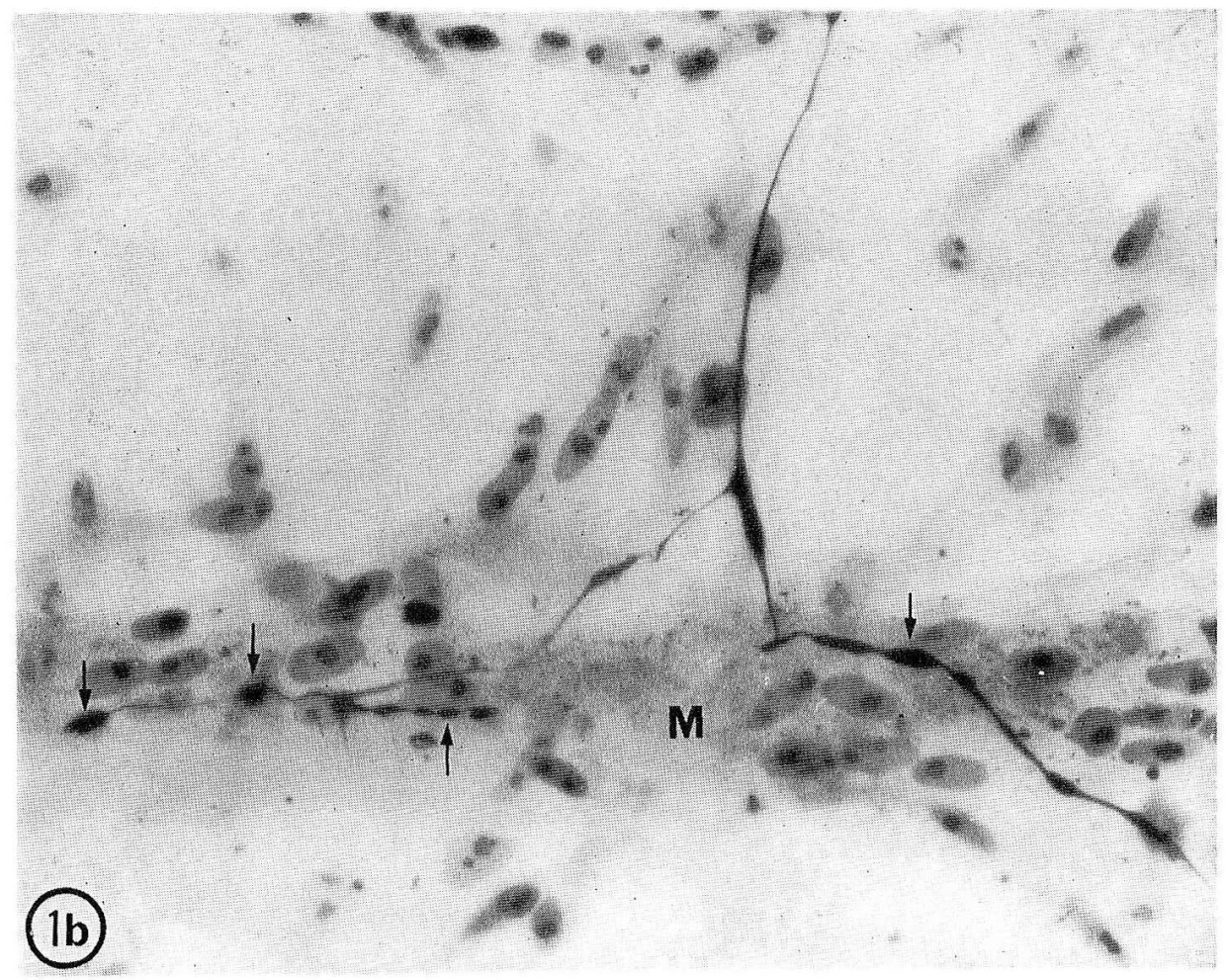

Fig. 1b. An enlargement of the squared-off region in Figure 1a. Note the bulbous swelling of the nerves (arrows) on the myotube $(M) \times 830$. (from: Shimada, Fischman and Moscona, 1969b; courtesy of Rockefeller University Press)

Fig. 1a. Six days in vitro. A nerve fiber $(N)$ runs along the upper surface of the myotube $(M)$, often branching near the intersection of two myotubes. Within the squared-off region multiple bulbous nerve endings are in contact with a myotube. $\times 330$. (from: SHimada, Fischman and Moscona, 1969b; courtesy of Rockcfeller University Press) 


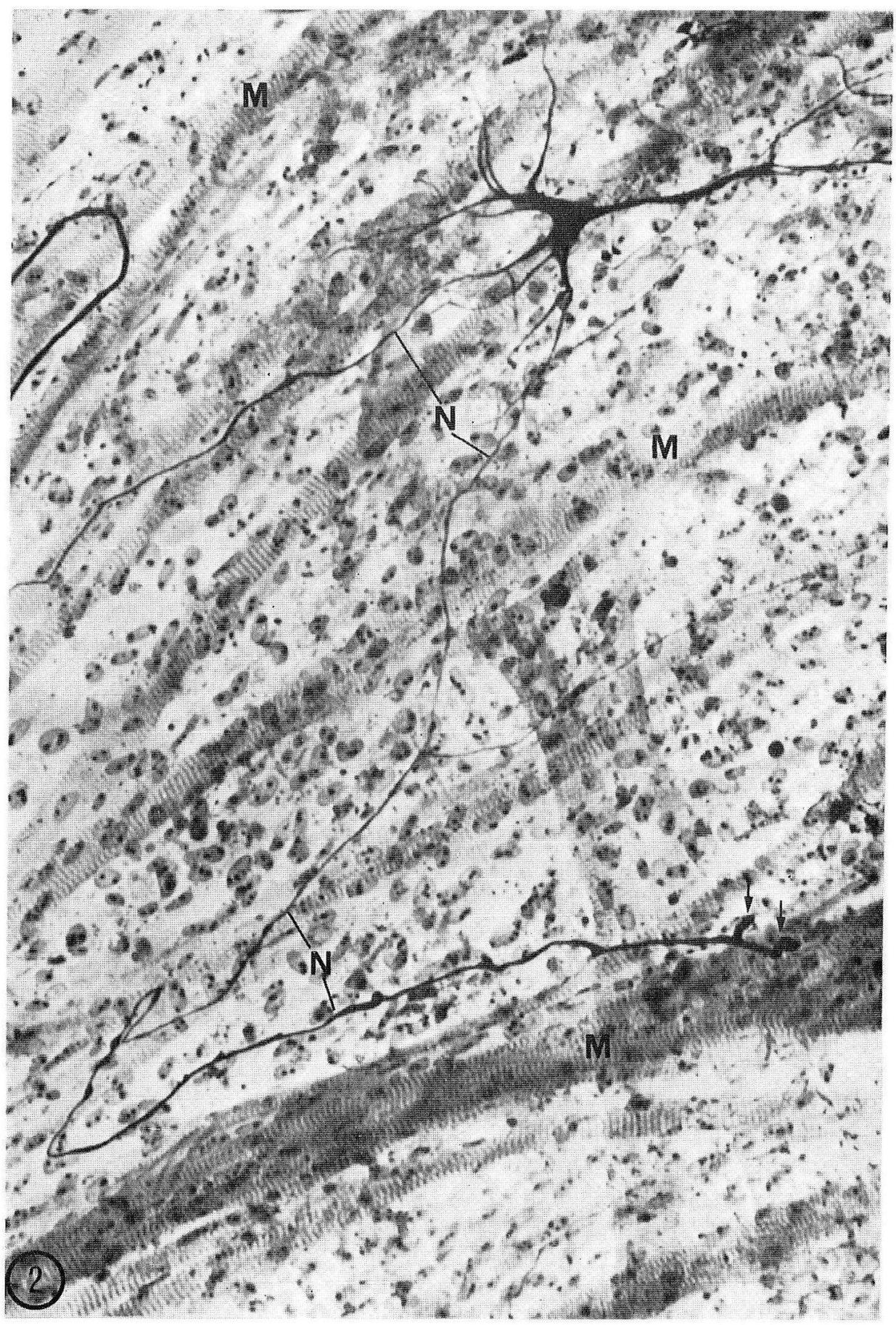

Fig. 2. Fourteen days in vitro. Extending from the multipolar neuron in this micrograph are extensive neuronal processes $(N)$. Bulbous thickenings of a nerve terminal are seen in contact with a muscle fiber (arrows). Numerous cross-striated muscle fibers are seen $(M) . \quad \times 390$ 


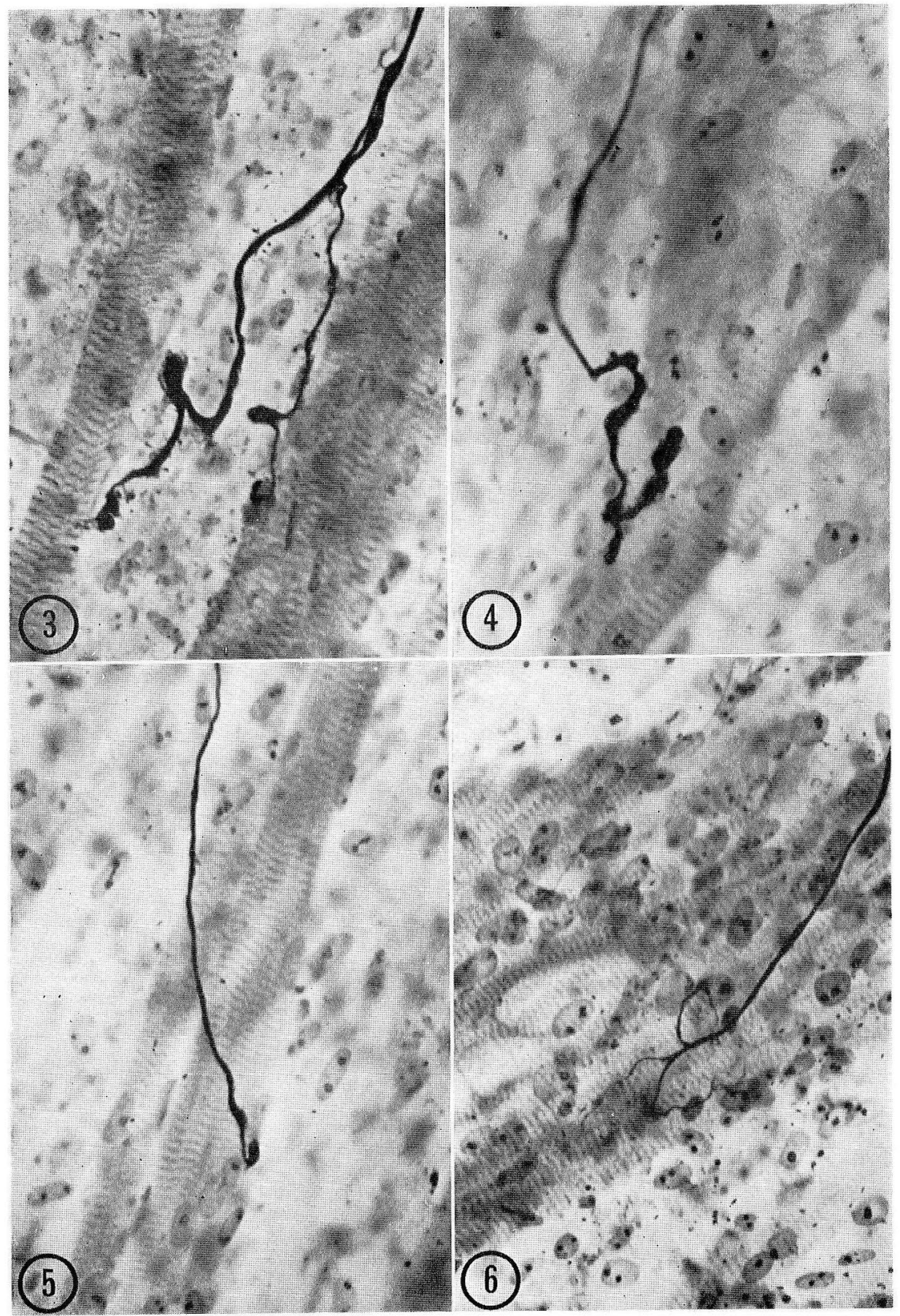

Fig. 3-6 Higher magnification of the contact region between nerve and muscle fibers in the 14 day cultures. The terminal nerve branches make contact with the muscle fibers by oval, buttonshaped extremities (termination en grappe) (Fig. 3-5). Linear endings (termination en ligne) are rarely seen (Fig. 6) $\times 660$. (Fig. 3, 4 from: Shimada, Fischman and Moscona, 1969a, courtesy of National Academy of Sciences, Washington) 


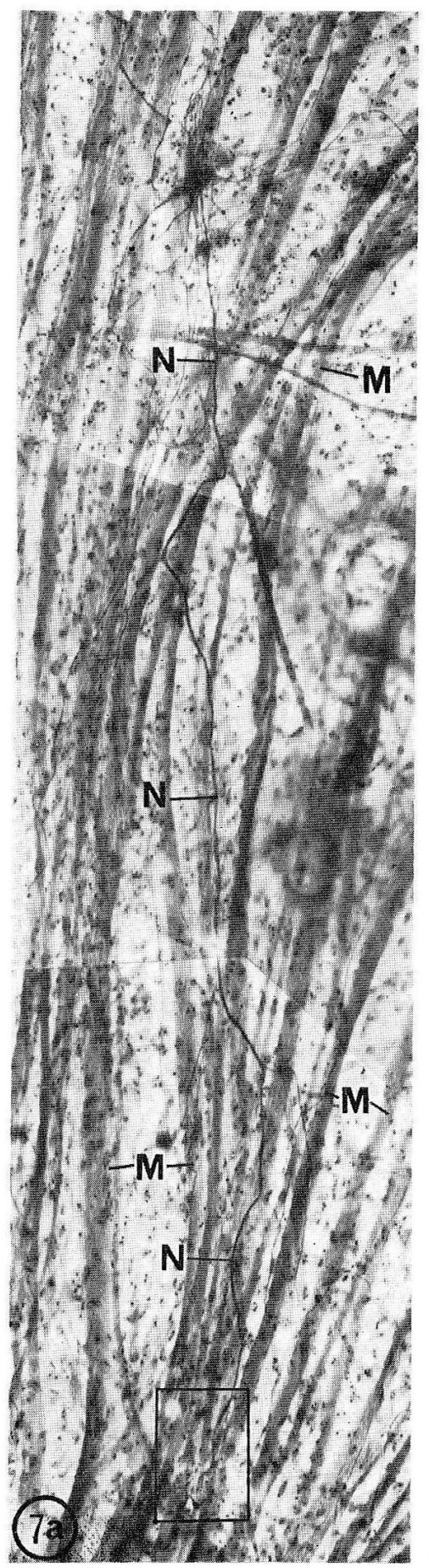

The data shows that the contacts of the nerve with initially dissociated muscle cells are also functional.

FISCHBACH (1970), examining electrophysiologically the cultures of dissociated nerve and muscle cells, recorded randomly occurring rapid potential fluctuations of about $0.5 \mathrm{mV}$, which resemble miniature endplate potentials (m.e.p.p.s), and larger sporadically occurring potential changes in definite patterns which resemble those of neuronal discharges. These results suggest the formation of functional neuromuscular connections in these cultures.

Kano and SHImada (1971a, 1971b), by the use of dissociated myoblasts cultured with spinal cord fragments (Fig. 9), have observed contractions of muscle fibers by the electrical stimulation of a spinal cord fragment, the muscle being within the distance of axonal growth in culture (nerve and muscle had been confronted for at least 8 days in vitro). Endplate potentials (e.p.p.s) were recorded with an intracellular microelectrode from these muscle fibers (Fig. 11A, D). D-tubocurarine blocked reversibly these evoked muscle potentials (Fig. $11 \mathrm{~A}-\mathrm{C}$ ), indicating that they are neurally evoked muscle potentials mediated by a chemical synaptic process at the neuromuscular junctions. The two different types of muscle fibers were found on ovservation of the shape of the e.p.p.s. One type of fiber generated e.p.p. without spikes, while the other with a spike. The former responded to a cord stimulation with a slow contraction, and the latter with a fast contraction. The former muscle fibers are similar to the slow muscle fibers in explants of chick (Li, ENGEL and KLATzo, 1959) and to the frog slow muscle fibers (Burke and GinsBorG, 1956; Kuffler and Vaughan Williams, 1953). Eserine did not have a marked effect on the size and time course of the e.p.p. (Fig. 11E). This simply indicates the relative lack of ChE activity on cultured muscle fibers as in fetal (Diamond and Miledi, 1962) and regenerated muscle fibers (Miledi, 1960). In fact, a ChE (Karnovsky and Roots, 1964) positive locus failed to be demonstrated histochemically on innervated muscle fibers. Thus, it can be said that esterase concentrations did not reach histochemically 
discernible levels by the time the cultures were examined. M.e.p.p.s were recorded from innervated muscle fibers (Fig. $11 \mathrm{~F}$ ) which could be blocked by d-tubocurarine. Iontophoretic application of acetylcholine $(\mathrm{ACh})$ showed that in innervated muscle fibers the chemosensitivity was restricted to some regions (Fig. $11 \mathrm{H}-\mathrm{J}$ ), while in noninnervated fibers it spreads across the entire surface membrane as in muscle fibers differentiated in vitro in the absence of neural tissue (KANo, IsHikawa and SHImADA, 1971). Silver impregnation of these electrophysiologically examined cultures revealed that the structures indicative of motor endplates (en grappe) were found in the region cuinciding with the chemosensitive spot (Fig. 10a, 10b). This result indicates that chemosensitive receptors are located on the innervated part of the muscle fiber.

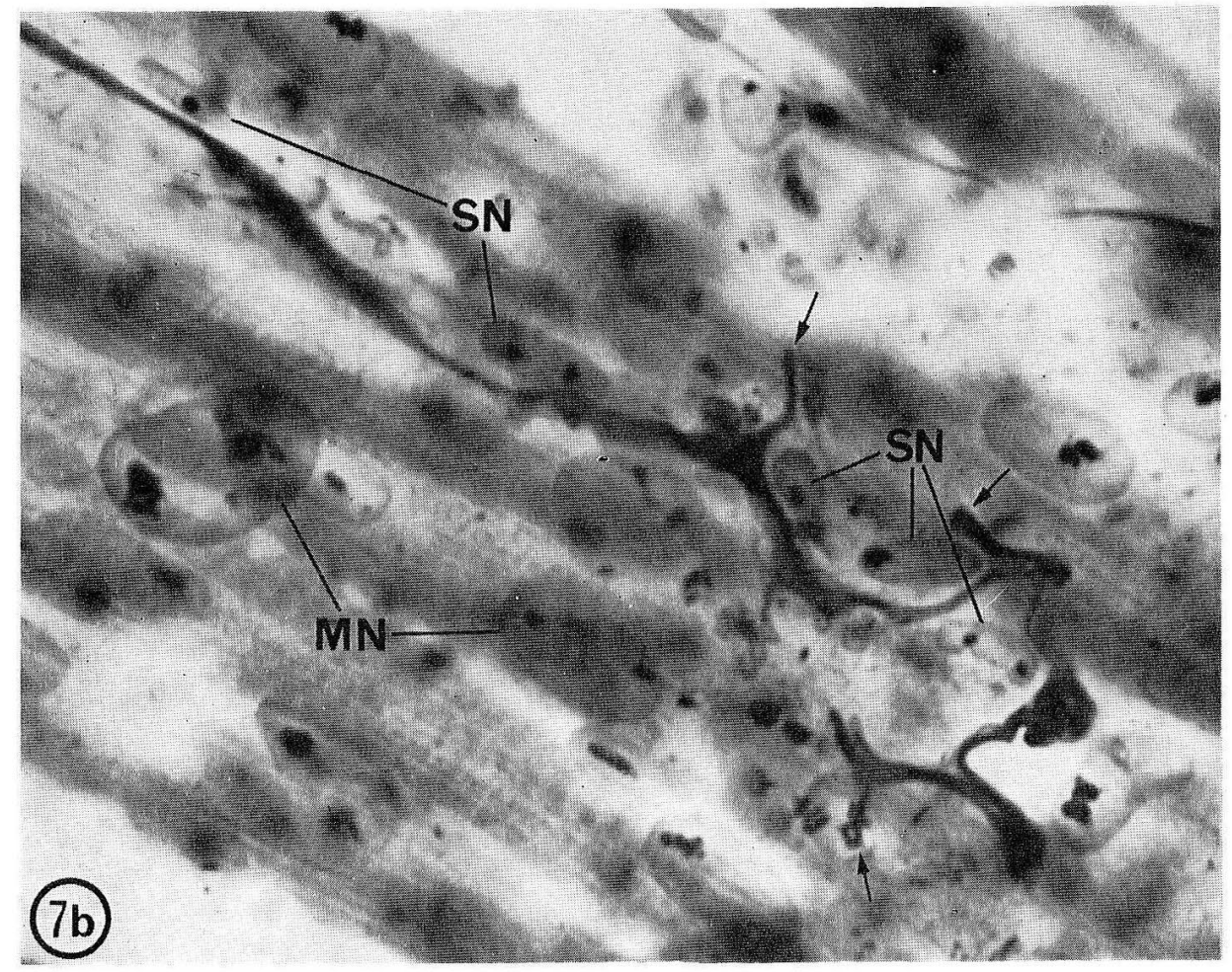

Fig. 7b. An enlargement of the rectangle in Figure 7a. Rather than the bulb-type endings seen in the 6 and 14 day cultures, the nerve endings (arrows) after 20 days appear as complexly branched, finger-like projections directly applied to the muscle (termination en plaque). Small oval nuclei (SN) which can be distinguished from muscle nuclei $(M N)$ are often associated with the nerve terminal. These small nuclei are tentatively identified as Schwann cell nuclei. $\times 1,400$. (from: SHimada,

Fischman and Moscona, 1969b; courtesy of Rockefeller University Press)

Fig. 7a. Twenty days in vitro. A neuron sends out a process $(N)$ which courses along the muscle cells. Within the squared-off region a well-developed nerve ending is seen. $M$ muscle fibers. $\times 180$. (from: Shimada, Fischman and Moscona, 1969b; courtesy of Rockefeller University Press) 


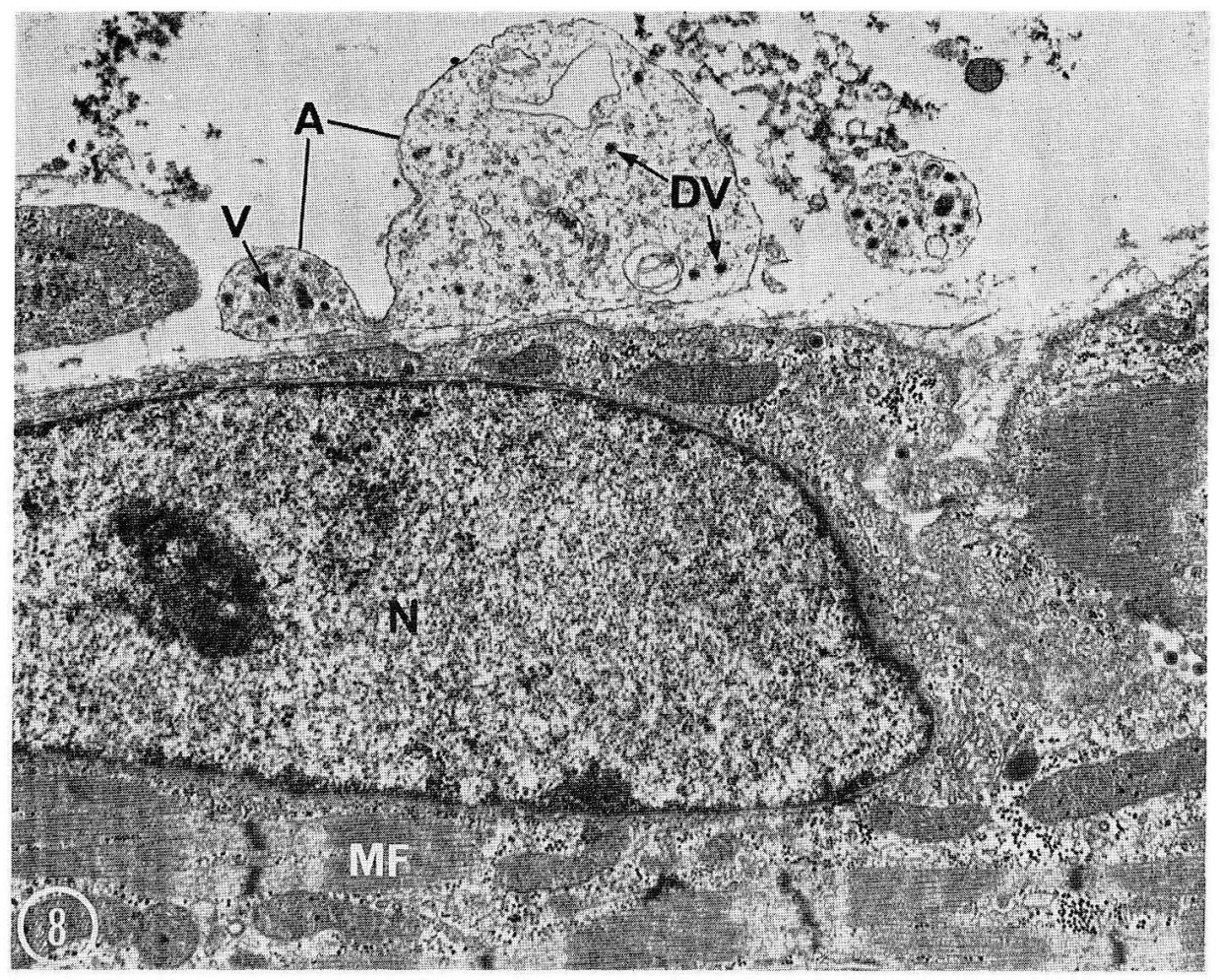

Fig. 8. Electron micrograph of a region near the motor endplate. An axon terminal $(A)$ lies adjacent to a muscle fiber. Clear vesicles $(V)$ and dense-cored vesicles $(D V)$ are seen in the terminal Monolayer culture of mixed spinal cord and skeletal muscle cells. Cultured for 14 days. $M F$ myofibrils, $N$ nucleas. $\times 13,000$

\section{Concluding Remarks}

It has been clarified that muscle fibers cultured in the absence of nerves have ACh sensitivity over their entire surface (Kano, Ishikawa and Shimada, 1971). Sensitivity to a transmitter substance may be a prerequisite for the establishment of a synaptic connection (Miledi, 1960, 1963; Katz and Miledi, 1964; Harris and Dennis, 1970). Thus, it can be said that cultured muscle fibers are suitable as "targets" to receive innervation.

What factors determine the course of outgrowing nerve fibers? Several hypotheses have been put forward to account for this phenomenon: chemotaxis (CAJAL, 1928), contact guidance (WEISS and TAYLOR, 1944), the tentacle theory (NAKAI, 1968),

Fig. 9. and 10. General view of cultures of dissociated embryonic muscle cells confronted with spinal cord fragments. Muscle fibers were confronted with spinal cord fragments (SC) at 4 days in vitro. Figures 9 and 10 are photographs from different cultures.

Fig. 9. Phase-contrast micrograph. 10 days in vitro. Well-differentiated muscle fibers $(M)$ are seen. Spinal cord cells send out axons over muscle fibers, but the axons are not visible in this micrograph. Muscle fibers innervated in vitro contract by electrical stimulation of the cord fragment. $\times 200$ 


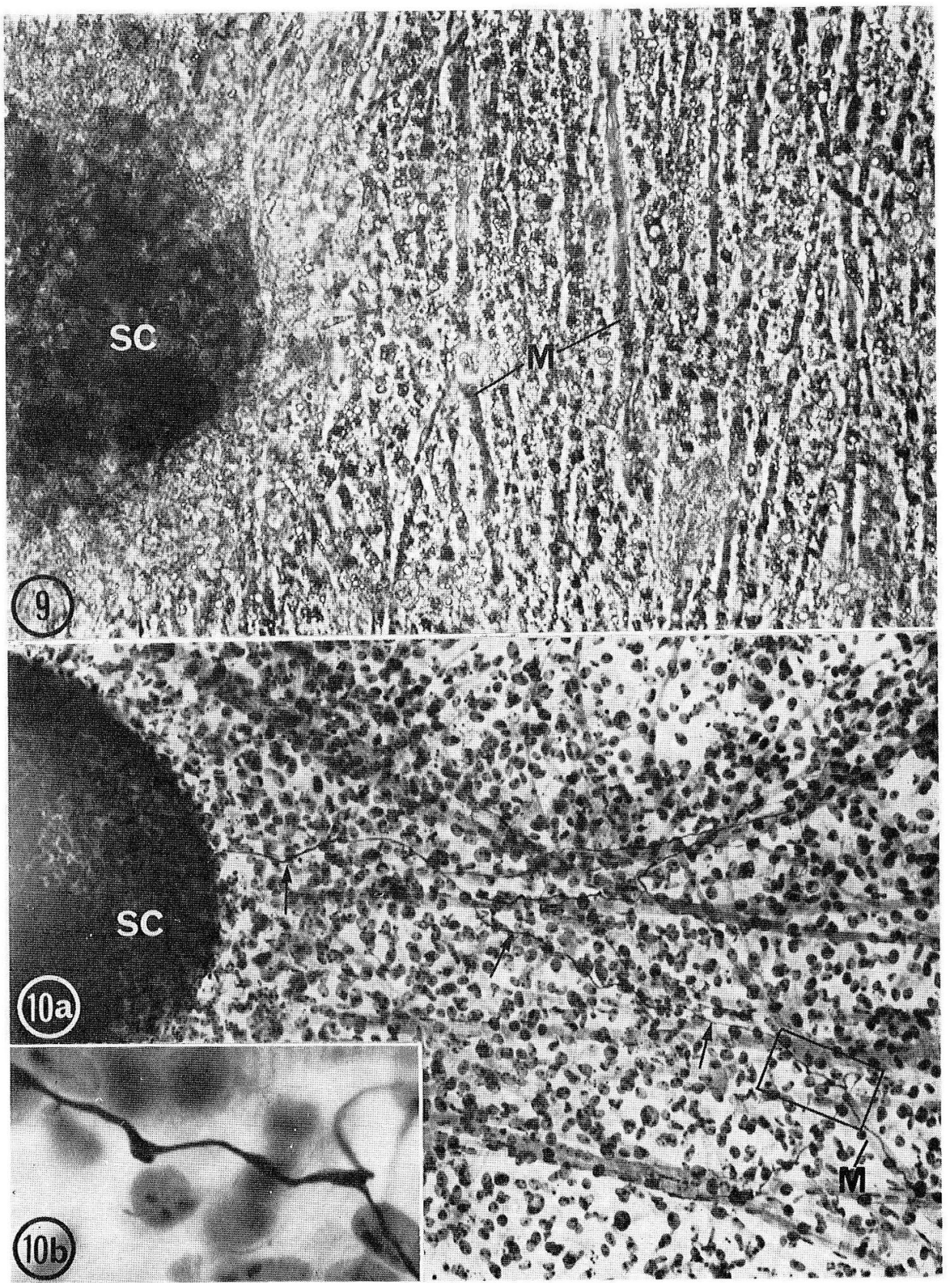

Fig. 10a. A silver stained whole-mount preparation impregnated after electrophysiological experiment. 19 days in vitro. At the region coinciding with the ACh sensitive spot on an innervated muscle fiber $(M)$, an axon terminal is seen (rectangle). This axon can be traced back to the spinal cord (arrows). $\times 200$

Fig. 10b. A higher magnification of the rectangle in Figure 10a. Characteristic swellings of the axon in contact with the muscle fiber are seen. $\times 1,000$ 

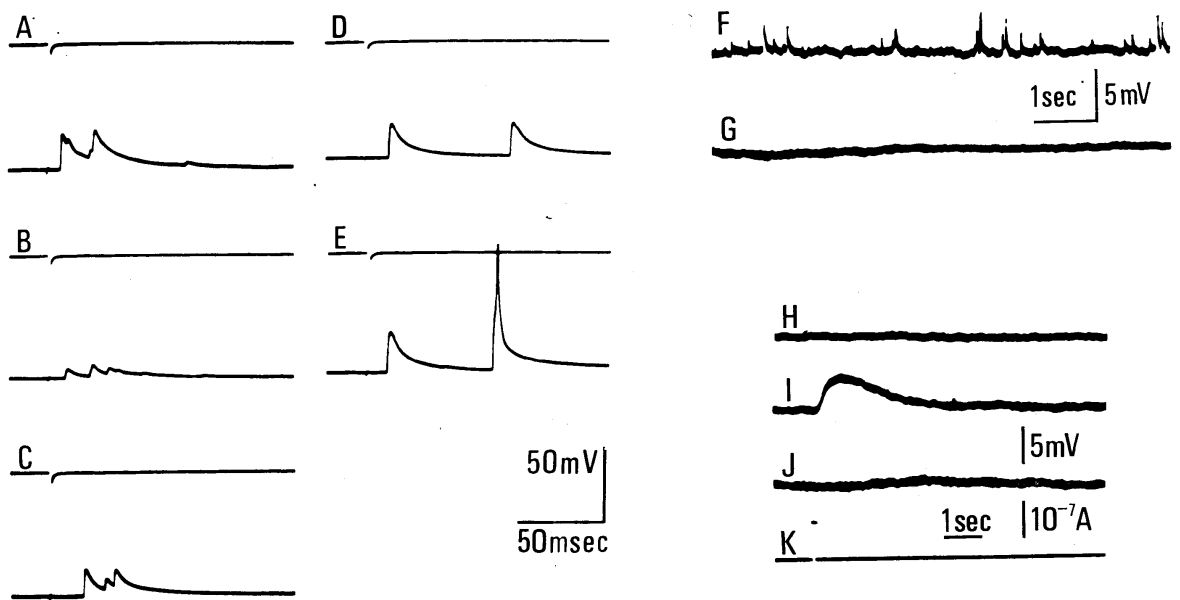

Fig. 11. Bioelectric records from cultures as in Figures 9-10.

Fig. 11 A-E. Neuromuscular transmission between spinal cord fragment and muscle fibers differentiated in vitro (12 day culture). Intracellular recording of e.p.p.s and action potential from muscle fibers. The upper tracing in each record indicates zero membrane potential level. Single electrical stimulus was applied through a saline-filled pipette into the spinal cord fragment. A: control record, B: after applying d-tubocurarine $(1 \mu \mathrm{g} / \mathrm{ml}), \mathbf{C}$ : after washing out dtubocurarine, D: control record from another muscle fiber, $\mathbf{E}$ : after applying eserine $(0.5 \mu \mathrm{g} / \mathrm{ml})$.

Fig. 11F-G. Intracellular recording from muscle fibers differentiated in vitro (19 day culture). F: m.e.p.p.s recorded from innervated muscle fiber, G: no m.e.p.p.s in non-innervated muscle fiber.

Fig. 11H-K. Sensitivity to ACh along an innervated muscle fiber (19 day culture). ACh was applied locally to different regions of the muscle fiber by iontophoretic method of DEL CASTILLO and KATZ (1955). The current through the ACh electrode is monitored in $\mathbf{K}$. ACh produced membrane depolarization only when applied to the endplate region $(\mathbf{I})$ but had no effect when applied at a distance of about $200 \mu$ at either side of the endplate region $(\mathbf{H}, \mathbf{J})$.

etc. However, from the nerve-muscle culture studies reviewed here, the question about what factors make motoneurons synapse with muscle fibers could not be solved. It still remains to be clarified how the neuronal tips determine their own targets.

ACh sensitivity on cultured muscle membrane became restricted to the motor endplate region after innervation had been established as has been demonstrated in regenerated (MilEdi, 1960) and in new-born muscle fibers (DiAMOND and Miledi, 1962). It is becoming increasingly evident that motor nerve fibers exert upon muscle fibers influences which are very different from the mere conduction of electric impuleses, i.e. "trophic influence of nerve on muscle" (GuTH, 1968). The neural control of ACh sensitivity of muscle fiber membrane is a prime example of neurotrophic influences. However, it is not clear how the nerve restricts ACh sensitivity to the junctional region. It is necessary to consider mechanisms other than transmitter release (MILEDI, 1960). JAMES and TRESMAN (1969) have noted "pinocytosis" of axon by myoblast at the initial stage of adherence in their cultures. This may suggest the possibility that these contacts could be preferential sites where active uptake of axonal material may occur. Recently, FAMBROUGH (1970) has shown that inhibitors of RNA and protein synthesis prevent the development of extrajunctional ACh sensitivity and concluded 
that the neural restriction of ACh sensitivity in muscle fiber involves regulation of gene activity in muscle fibers.

Functional synapses did not form between every axon and muscle cell that appeared to be contacted under phase microscopy (FIsснвасн, 1970). Such "failures" might reflect a non-specific tissue antagonism, immaturity, unfavorable culture conditions, or inexcitability of the neurons. Thus, the optimal conditions for the formation of functional neuromuscular synapses at maximum frequency in culture remains to be fully worked out.

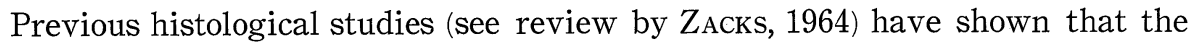
morphology of motor nerve endings differs, depending upon the type of muscle (phasic and tonic) which is innervated. Buller, Eccles and Eccles (1960) have found that nerve fibers control the differentiation of muscle into phasic and tonic muscles. The nerve-muscle culture systems described here lend themselves to detailed studies along these lines. The type of innervation in various combinations of nerve and skeletal muscle cells from different embryonic regions should be clarified, and thus the problems of specificity and recognition during neuromuscular development must be examined. Furthermore, it should be possible to study the development of nerveheart and smooth muscle junctions in vitro, which has not yet been done in detail (Masurovsky and Benitez, 1967; Shimizu, Rikimaru and Nagasawa, 1968).

\title{
組織培養による神経筋接合の形成
}

\author{
嶋田裕と加濃正明
}

組織培養で神経筋接合を形成させようという試みは，今世紀初頭からあったが，最近 ようやくその成功例が報告されるようになってきた.つぎの培養法で形態学的にまた 電気生理学的に, 神経筋接合の形成されることが報告されている. (1)脊髄片とそれに付 属する筋節の器官培養, (2) 金髄片と筋片を並べての器官培養, (3)筋芽細胞の単層培養に 会髄片または会髄神経細胞を加えた培養. また 異種動物間にも神経筋接合の形成される ことが報告されている.これらの培養法は 神経支配の機構をしらべる上に, 有を効な研究 手段であると思われる。

\section{References}

Anggard, L. and D. Ottoson: Observations on the functional development of the neuromuscular apparatus in fetal sheep. Exp. Neurol. 7: 294-304 (1963).

Bornstein, M. B. and L. M. Breitbart: Anatomical studies of mouse embryo spinal cord-skeletal muscle in long-term tissue culture. Anat. Rec. 148: 362 (Abstr.) (1964).

Bornstein, M. B., H. Iwanami, G. M. Lehrer and L. Breitbart: Observations on the appearance of neuromuscular relationships in cultured mouse tissues. Z. Zellforsch. 92: 197-206 (1968).

Buller, A. J., J. C. Eccles and R. M. Eccles: Interactions between motoneurones and muscles in respect of the characteristic speeds of their responses. J. Physiol. 150: 417-439 (1960).

Burke, W. and B. L. Ginsborg: The electrical properties of the slow muscle fibre membrane. J. Physiol. 132: 586-598 (1956). 
Cajal, S. Ramon y: Degeneration and regeneration of the nervous system Translated and edited by R. M. May. London, Oxford Univ. Press. Vol. 1. (1928).

Corner, M. A.: Localization of capacities for functional development in the neural plate of Xenopus laevis. J. comp. Neurol. 123: 243-256 (1964a).

-: Rhythmicity in the early swimming of anuran larvae. J. Embryol. exp. Morphol. 12: 665$671(1964 \mathrm{~b})$.

Corner, M. A. and S. M. Crain: Spontaneous contractions and bioelectric activity after differentiation in culture of presumptive neuromuscular tissues of the early frog embryo. Experientia 21: 422-424 (1965).

Crain, S. M.: Electrophysiological studies of cord-innervated skeletal muscle in long-term tissue cultures of mouse embryo myotomes. Anat. Rec. 148: 273 (Abstr.) (1964).

- : Muscle. Electrophysiology. In: (ed. by) E. N. Willmer: Cells and tissues in culture. London, Academic Press. 2: 335-339; 344-347 (1965).

- D Development of "organotypic" bioelectric activities in central nervous tissues during maturation in culture. Int. Rev. Neurobiol. 9: 1-43 (1966).

-: Development of functional neuromusucular connections between separate explants of fetal mammalian tissues after maturation in culture. Anat. Rec. 160: 466 (Abstr.) (1968).

-: Bioelectric interactions between cultured fetal rodent spinal cord and skeletal muscle after innervation in vitro. J. exp. Zool 173: 353-370 (1970).

Crain, S. M., L. Alfei and E. R. Peterson: Neuromuscular transmission in cultures of adult human and rodent skeletal muscle after innervation in vitro by fetal rodent spinal cord. J. Neurobiol. 1: 471-487 (1970).

Csillik, B.: Contributions to the development of the myoneural synapses. Ontogenetic aspects of the subneural apparatus. Z. Zellforsch. 52: 150-162 (1960).

del Castillo, J. and B. Katz: On the localization of acetylcholine receptors. J. Physiol. 128: 157181 (1955).

Diamond, J. and R. Miledi: A study of foetal and new-born rat muscle fibres. J. Physiol. 162: 393-408 (1962).

Fambrough, D. M.: Acetylcholine sensitivity of muscle fiber membranes: mechanisms of regulation by motoneurons. Science 168: 372-373 (1970).

Filogamo, G. and G. Gabella: The development of neuromuscular correlations in vertebrates. Arch. Biol. 78: 9-60 (1967).

Fischbach, G. D.: Synaptic potentials recorded in cell cultures of nerve and muscle. Science 169: 1331-1333 (1970).

Gonzalez, A. W.: The prenatal development of behavior in the albino rat. J. comp. Neurol. 55: 395-442 (1932).

Guth, L.: “Trophic" influences of nerve on muscle. Physiol. Rev. 48: 645-687 (1968).

Harris, A. J. and M. J. Dennis: Acetylcholine sensitivity and distribution on mouse neuroblastoma cells. Science 167: 1253-1255 (1970).

Harrison, R. G.: Observations on the living developing nerve fiber. Proc Soc. exp. Biol. Med. 4: 140-143 (1907).

Hirano, H.: A histochemical study of the cholinesterase activity in the neuromuscular junction in developing chick skeletal muscles. Arch. histol. jap. 28: 89-101 (1967a).

- : Ultrastructural study on the morphogenesis of the neuromuscular junction in the skeletal muscle of the chick. Z. Zellforsch. 79: 198-208 (1967b).

James, D. W. and R. L. Tresman: De novo formation of neuro-muscular junctions in tissue culture. Nature 220: 384-385 (1968).

: An electron-microscopic study of the de novo formation of neuromuscular junctions in tissue culture. Z. Zellforsch. 100: 126-140 (1969).

Kano, M. and Y. Shimada: Innervation of skeletal muscle cells differentiated in vitro from chick embryo. Brain Res. 27: 402-405 (1971a).

- Innervation and acetylcholine sensitivity of skeletal muscle cells differentiated 
in vitro from chick embryo. J. cell. Physiol. (in press) (1971b).

Kano, M., K. Ishikawa and Y. Shimada: Acetylcholine sensitivity of skeletal muscle cells differentiated in vitro from chick embryo. Brain Res. 25: 216-219 (1971).

Karnovsky, M. J.: The localization of cholinesterase activity in rat cardiac muscle by electron microscopy. J. Cell Biol. 23: 217-231 (1964).

Karnovsky, M. J. and L. Roots: A "direct-coloring" thiocholine method for cholinestrases. J. Histochem. Cytochem. 12:219-221 (1964).

Katz, B. and R. Miledi: The development of acetylcholine sensitivity in nerve-free segments of skeletal muscle. J. Physiol. 170: 389-396 (1964).

Kelly, A. M. and S. I. Zacks: The fine structure of motor endplate morphogenesis. J. Cell Biol. 42: 154-169 (1969).

Koelle, G. B. and J. S. Friedenwald: A histochemical method for localizing cholinesterase activity. Proc. Soc. exp. Biol. Med. 70: 617-622 (1949).

Kuffler, S. W. and E. M. Vaughan Williams: Small-nerve junctional potentials. The distribution of small motor nerves to frog skeletal muscle, and the membrane characteristics of the fibres they innervate. J. Physiol. 121: 289-317 (1953).

Kupfer, C. and G. B. Koelle: A histochemical study of cholinesterase during formation of the motor end plate of the albino rat. J. exp. Zool. 116: 397-413 (1951).

Li, C.-L., K. Engel and I. Klatzo: Some properties of cultured chick skeletal muscle with particular reference to fibrillation potential. J. cell. comp. Physiol. 53: 421-444 (1959).

Masurovsky, E. and H. H. Benitez: Apparent innervation of chick cardiac muscle by sympathetic neurons in organized culture. Anat. Rec. 157: 285 (Abstr.) (1967).

Miledi, R.: Junctional and extra-junctional acetylcholine receptors in skeletal muscle fibres. J. Physiol. 151: 24-30 (1960).

: Formation of extra-nerve-muscle junctions in innervated muscles. Nature 199: 1191-1192 (1963).

Murray, M. R.: Muscle. In: (ed. by) E. N. Willmer: Cells and tissues in culture. London, Academic Press. 2: 311-372 (1965a).

: Nervous tissues in vitro. In: (ed. by) E. N. Willmer: Cells and tissues in culture. London, Academic Press 2: 373-455 (1965b).

Nakai, J.: Morphological studies on the nerve growth cone. Acta anat. nippon. 43: 12-13 (Abstr.) (1968).

-: The development of neuromuscular junctions in cultures of chick embryo tissues. J. exp. Zool. 170: 85-106 (1969).

Peterson, E. R., L. Alfei and S. M. Crain: Innervation in vitro of adult human and rodent skeletal muscle by fetal neurons from rodent spinal cord. J. Cell Biol. 43: 104a (Abstr.) (1969). : Regeneration and innervation, de novo, of adult skeletal muscle in vitro. J. Neuropathol. exp. Neurol. 29: 134 (Abstr.) (1970).

Peterson, E. R. and S. M. Crain: Re-innervation of denervated mammalian skeletal muscle in vitro Anat. Rec. 160: 408-409 (Abstr.) (1968).

: Innervation in cultures of fetal rodent skeletal muscle by organotypic explants of spinal cord from different animals. Z. Zellforsch. 106: 1-21 (1970).

Peterson, E. R., S. M. Crain and M. R. Murray: Differentiation and prolonged maintenance of bioelectrically active spinal cord cultures (rat, chick and human). Z. Zellforsch. 66: 130-154 (1965)

Shimada, Y.: Suppression of myogenesis by heterotypic and heterospecific cells in monolayer cultures. Exp. Cell Res. 51: 564-578 (1968).

Shimada, Y., D. A. Fischman and A. A. Moscona: Formation of neuromuscular junctions in embryonic cell cultures. Proc. nat. Acad. Sci. U.S 62: 715-721 (1969a).

of embryonic spinal cord and skeletal muscle cells. J. Cell Biol. 43: 382-387 (1969b).

Shimizu, Y., A. Rikimaru and J. Nagasawa: Studies on the innervation of intestinal smooth 
muscle by organ culture technique. Tissue culture studies in Japan. The annual bibliography. 85-86 (Abstr.) (1968).

Szepsenwol, J.: A comparison of growth, differentiation, activity and action currents of heart and skeletal muscle in tissue culture. Anat. Rec. 95: 125-146 (1946).

-: Electrical excitability and spontaneous activity in explants of skeletal and heart muscle of chick embryos. Anat. Rec. 98: 67-85 (1947).

Teräväinen, H.: Development of the myoneural junction in the rat. Z. Zellforsch. 87: 249-265 (1968).

Veneroni, G.: Formation de novo and development of neuromuscular junctions. Anat. Rec. 160:503 (Abstr.) (1968a).

-: In vitro neoformation and development of neuromuscular junctions. Boll. Soc. Ital. Biol. Sper. 44: 1119-1121 (1968b).

Veneroni, G. and M. R. Murray: Formation de novo and development of nuromuscular junctions in vitro. J. Embryol. exp. Morph. 21: 369-382 (1969).

Weiss, P. and A. C. Taylor: Further experimental evidence against neurotropism in nerve regeneration. J. exp. Zool 95: 233-257 (1944).

Windle, W. F.: The neurofibrillar structure of the spinal cord of cat embryos correlated with the appearance of early somatic movements. J. comp. Neurol. 53: 71-106 (1931).

-: Correlation between the development of local reflexes and reflex arcs in the spinal cord of cat embryos. J. comp. Neurol. 59: 487-509 (1934).

Windle, W. F. and R. E. Baxter: Development of reflex mechanisms in the spinal cord of albino rat embryos. Correlation between structure and function, and comparisons with the cat and the chick. J. comp. Neurol. 63: 189-210 (1936).

Windle, W. F., W. L. Minear, M. F. Austin and D. W. Orr: The origin and early development of somatic behavior in th albino rat. Physiol. Zool. 8: 156-185 (1935).

Zacks, S. I.: The motor endplate. Philadelphia, W. B. Saunders Co., 1964.

Zelena, J. und J. Szentágothai: Verlagerung der Lokalisation spezifischer Cholinesterase während der Entwicklung der Muskelinnervation. Acta histochem. 3: 284-296 (1957).

Noted Added in Proof. While this munuscript was in press a paper appeared (Robbins, N. and T. Yonezawa: Developing neuromuscular junctions: first signs of chemical transmission during formation in tissue culture. Science 172: 395-398, 1971) in which neuromuscular transmission was demonstrated electrophysiologically in the early stage of nerve-muscle contacts in cultures of spinal cord fragments confronted with skeletal muscle fragments or dissociated myoblasts.

\author{
嶋田裕 \\ 于280 千葉市亥鼻町 313 \\ 千葉大学医学部 \\ 解剖学教室
}

Dr. Yutaka SHimada

Department of Anatomy

Chiba University School of Medicine

280 Chiba, Japan 